\title{
BCCin4
}

\section{USE OF LATEX IN CELLULOSE FIBERS AND REPLACEMENT WITH METACAULIM FOR APPLICATION IN COMPOSITES WITH CEMENT MATRIX}

\author{
Rondinele Alberto dos Reis Ferreira (1), Lara Cristina Péres dos Santos (1), Leila \\ Aparecida de Castro Motta ${ }^{(1)}$ and Daniel Pasquini (2)
}

(1) Civil Engineering School, Federal University of Uberlandia, Uberlandia, MG, Brazil

(2) Institute of Chemistry, Federal University of Uberlandia, Uberlandia, MG, Brazil

https://doi.org/10.21452/bccm4.2018.02.11

\begin{abstract}
In this work, it was studied the addition of latex in cellulose pulps in cement matrices. It is known that the alkalinity of the matrix degrades the fiber. Therefore, in addition of latex in fiber, the alkalinity of the matrix was reduced by replacing part of the cement with metakaolin. The influence of the analyzed parameters (percentage of cellulose, the percentage of latex and percentage of metakaolin) on the mechanical and physical properties of the cement composites was evaluated through an experimental planning. From this planning, it was possible to develop a model of equations that optimized the results of the modulus of rupture and water absorption. Flexural strength and water absorption tests were made on composites at 28 days of age. It was observed that the best conditions analyzed to maximize the value of the rupture modulus was the combinations of the values of cellulose in $8.5 \%$, of latex in the value of $0.249 \%$ and of metakaolin in the central point (19\%), resulting in the value for rupture modulus of $14.5 \mathrm{MPa}$. Regarding the absorption, it was observed that only the cellulose variable was significant for this response. Higher concentrations of cellulose resulted in higher values for percentage of absorption, due to the hydrophilicity of the natural fiber.
\end{abstract}

Keywords: Cellulose fiber, latex, metakaolin, mechanical properties, absorption

\section{INTRODUCTION}

Sustainability is the ability to meet the needs of the present without compromising future generations. However, one of the main problems faced by the construction industry is the generation of waste, the scarcity of natural resources, the consumption of energy, the emission of gases, that is, the impact caused to the environment. In this sense, numerous searches are being carried out with the objective of guaranteeing environmental preservation with renewable materials or the reuse of industrial waste. The plant fibers are worthy of note observation because they present interesting properties, such as good mechanical performance in fragile matrices, high availability, renewable source and low cost of production [1,2]. Several studies 
are focused on the treatment of fibers, or even the matrix, to enable their use in the long term. Among the treatments is the reduction of the alkalinity of the matrix by the replacement of part of the cement by pozzolanic materials [3] or by accelerated carbonation [4]. Chemical treatments of the fibers (alkaline treatment) [5] and acetylation [6]. Finally, physical treatments such as thermomechanical treatment [7] and hornification [8] can also be applied. The aim of the present study was to study the physical treatment of cellulose fibers with the addition of natural rubber latex, and the reduction of alkalinity of the cement matrix, with the replacement of part of the cement by metakaolin in the manufacture of cementitious composites.

\section{MATERIALS AND METHODS}

\subsection{Characteristics of cellulose, cement, latex and metakaolin}

The composites were molded using cellulose, with the specific mass of $1.5 \mathrm{~g} / \mathrm{cm}^{3}$, extracted from Eucalyptus urograndis, processed industrially by the Kraft method, and supplied by Suzano (Limeira/SP). The sheets of Kraft paper have a length, width and thickness of approximately $39.5 \mathrm{~cm}, 31 \mathrm{~cm}$ and $0.13 \mathrm{~cm}$, respectively. The cement used was the Ultra Fast CPV ARI, of the Holcim brand. The solids content of the latex was obtained according to the parameters determined in ASTM D 1076-02. Natural rubber latex with a solids content of 43.33\% by weight was supplied by Fazenda Varginha, located in Araguari, Minas Gerais. The latex was extracted directly from the rubber tree (Heveabrasilensis). Metacaulim HP ULTRA, awarded by Metacaulim do Brasil (Jundiaí-SP). This product consists of $\mathrm{SiO}_{2}$ and $\mathrm{Al}_{2} \mathrm{O}_{3}$ in the amorphous phase. Furthermore, the average particle diameter is $12.4 \mu \mathrm{m}$ and a specific mass of approximately $2.65 \mathrm{~kg} / \mathrm{m}^{3}$ [9].

\subsection{Preparation of the composites and design of experiments}

The mixing and preparation of the composites were carried out using the principle of the Hatschek process, developed by Ludwing Hatschek [10]. Initially, the cellulose was incorporated into the water, followed by latex, cement and metakaolin. To each material added to the mixer, the mixture was stirred for 5 min until its complete homogenization. The mass solids concentration, for each composite, was $40.2 \%$. The specimens had dimensions of $20 \mathrm{~cm}$ $\mathrm{x} 20 \mathrm{~cm}$ the side and $4 \mathrm{~mm}$ in thickness.

In order to carry out the experimental planning, cement composites with fixed volume were molded $\left(160 \mathrm{~cm}^{3}\right)$. The planning was elaborated for $\alpha$ of orthogonality of 1.41421 . The limits of the factors studied for percentage of cellulose in the mixture $-\mathrm{X}_{1}$ (the largest additions of mechanical resistance in the pulp), latex $\left(\mathrm{X}_{2}\right)$ and metakaolin $\left(\mathrm{X}_{3}\right)$ (percentage used as an addition in cement composites cited in the literature) are shown in Table 1. The studied responses were the modulus of rupture and absorption. Flexural tests was performed at 28 days. The recommendations and parameters contained in [11] was adopted. An INSTRON universal test machine, model 5982 and a load cell of $5 \mathrm{kN}$ were used. Water absorption tests were also carried out according to ASTM C 948-81 (2009).

\section{RESULTS AND DISCUSSION}

\subsection{Statistical analysis - Effect of independent variables}

Table 1 shows the experimental conditions studied in central composite design (CCD) matrix, with uncoded values of parameters and results obtained for modulus of rupture (MR) and absorption (A). The equations obtained by multiple regression to represent the modulus of rupture and absorption as a function of the independent variables studied can be visualized in equations 1 and 2, respectively. 
$4^{\text {th }}$ Brazilian Conference on Composite Materials. Rio de Janeiro, July $22^{\text {nd }}-25^{\text {th }}, 2018$

Table 1: The experimental conditions studied in CCD matrix, with coded and uncoded values of parameters

\begin{tabular}{|c|c|c|c|c|c|}
\hline$E$ & $\begin{array}{c}\text { Cel }^{1} \\
\% \\
\text { (coded) }\end{array}$ & $\begin{array}{c}\text { Lat }^{2} \\
\% \\
\text { (coded) }\end{array}$ & $\begin{array}{c}\mathrm{Mk}^{3} \\
\% \\
\text { (coded) }\end{array}$ & $\begin{array}{l}\text { Modulus of } \\
\text { rupture } \\
(\mathrm{MPa})\end{array}$ & $\begin{array}{c}\text { Absorption } \\
\text { (\%) }\end{array}$ \\
\hline 1 & $1.50(-1)$ & $0.02(-1)$ & $4(-1)$ & 9.11 & 10.28 \\
\hline 2 & $1.50(-1)$ & $0.02(-1)$ & $34(+1)$ & 8.85 & 10.76 \\
\hline 3 & $1.50(-1)$ & $0.21(+1)$ & $4(-1)$ & 7.23 & 11.51 \\
\hline 4 & $1.50(-1)$ & $0.21(+1)$ & $34(+1)$ & 8.78 & 13.17 \\
\hline 5 & $8.50(+1)$ & $0.02(-1)$ & $4(-1)$ & 9.10 & 37.58 \\
\hline 6 & $8.50(+1)$ & $0.02(-1)$ & $34(+1)$ & 7.29 & 39.42 \\
\hline 7 & $8.50(+1)$ & $0.21(+1)$ & $4(-1)$ & 13.26 & 33.15 \\
\hline 8 & $8.50(+1)$ & $0.21(+1)$ & $34(+1)$ & 14.42 & 28.58 \\
\hline 9 & $0.05(-1.41)$ & $0.115(0)$ & $19(0)$ & 4.51 & 11.30 \\
\hline 10 & $9.95(+1.41)$ & $0.115(0)$ & $19(0)$ & 4.54 & 66.42 \\
\hline 11 & $5.00(0)$ & $0(-1.41)$ & $19(0)$ & 10.29 & 21.19 \\
\hline 12 & $5.00(0)$ & $0.249(+1.41)$ & $19(0)$ & 13.73 & 18.13 \\
\hline 13 & $5.00(0)$ & $0.115(0)$ & $0(-1.41)$ & 10.91 & 16.54 \\
\hline 14 & $5.00(0)$ & $0.115(0)$ & $40.2(+1.41)$ & 12.57 & 21.81 \\
\hline $15(\mathrm{C})$ & $5.00(0)$ & $0.115(0)$ & $19(0)$ & 11.42 & 19.34 \\
\hline $16(\mathrm{C})$ & $5.00(0)$ & $0.115(0)$ & $19(0)$ & 12.47 & 24.03 \\
\hline $17(\mathrm{C})$ & $5.00(0)$ & $0.115(0)$ & $19(0)$ & 9.03 & 21.00 \\
\hline $18(\mathrm{C})$ & $5.00(0)$ & $0.115(0)$ & $19(0)$ & 10.93 & 25.23 \\
\hline
\end{tabular}

${ }^{1}$ Cellulose; ${ }^{2}$ Latex; ${ }^{3}$ Metakaolin.

$$
\begin{aligned}
& (\mathrm{MR})=10.7+0.8\left(\mathrm{X}_{\mathrm{cel}}\right)-2.9\left(\mathrm{X}_{\mathrm{cel}}\right)^{2}+1.2\left(\mathrm{X}_{\mathrm{Lat}}\right)+0.9\left(\mathrm{X}_{\mathrm{Lat}}\right)^{2}+0.25\left(\mathrm{X}_{\mathrm{Mk}}\right)+0.8\left(\mathrm{X}_{\mathrm{Mk}}\right)^{2}+1.7\left(\mathrm{X}_{\mathrm{cel}}\right) \\
& \left(\mathrm{X}_{\text {Lat }}\right)-0.24\left(\mathrm{X}_{\mathrm{cel}}\right)\left(\mathrm{X}_{\mathrm{Mk}}\right)+0.6\left(\mathrm{X}_{\text {Lat }}\right)\left(\mathrm{X}_{\mathrm{Mk}}\right)
\end{aligned}
$$

It was observed that equation 1 significantly represented the modulus of rupture (MR) response, with a coefficient of variation $\left(\mathrm{R}^{2}\right)$ of 0.90 , for a confidence level of $90 \%$. In this way, it was possible to construct the response surfaces for the modulus rupture (Figure 1). 

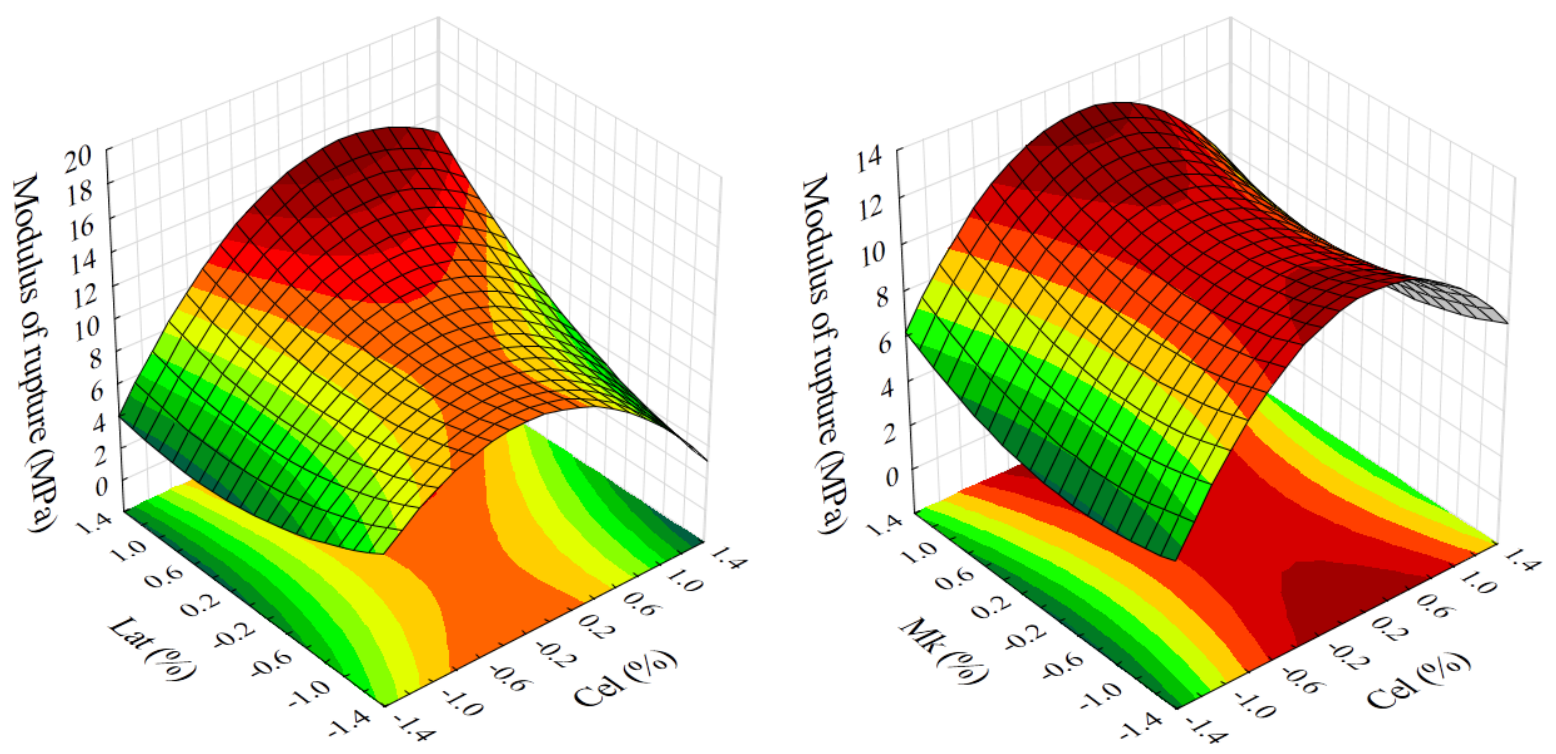

(c)

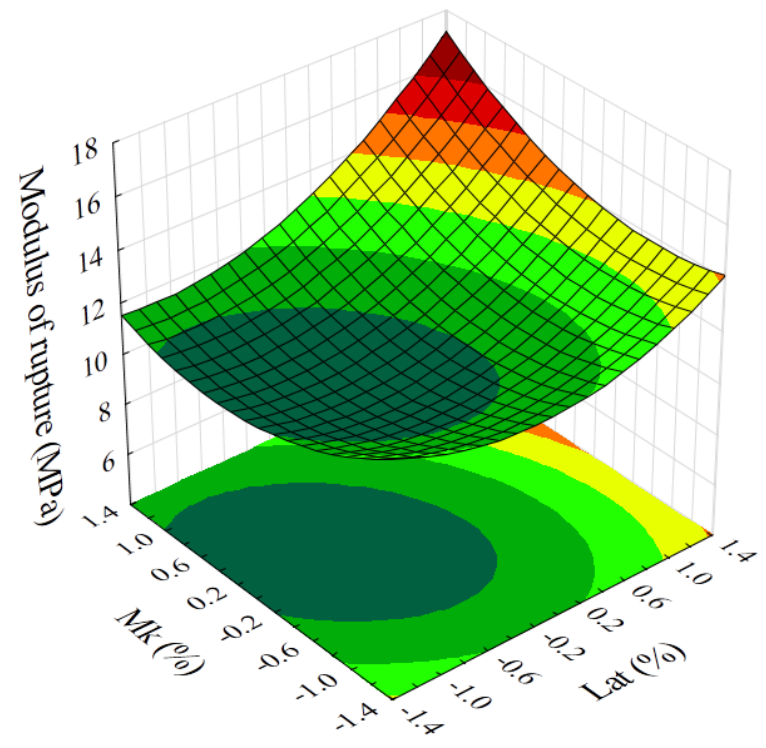

Figure 1: Surface response to the modulus of rupture - (a)\% metakaolin in the central level $\left(\mathrm{X}_{3}\right.$ $=0)$; (b) \% latex in the central level $\left(\mathrm{X}_{2}=0\right)$; (c) \% cellulose in the central level $\left(\mathrm{X}_{1}=0\right)$

According to Figure 1a it was possible to observe the influence of the variables $\mathrm{X}_{1}$ (cellulose) and $\mathrm{X}_{2}$ (latex) in the modulus of rupture of the composite. The figure presented five regions. Among these regions it is worth mentioning the maximum point located at the intersection of the maximum concentration of latex, in the coded value of 1.41 , equivalent to the decoded value of $0.249 \%$, and the coded value of cellulose around 1.0 , equivalent to $8.5 \%$ (decoded), resulting in a rupture modulus value of $14.5 \mathrm{MPa}$. This result can be justified by the rough surface of the fiber that conditions an appropriate anchorage and an adequate reinforcement [12]. In addition, possibly, the presence of a greater amount of latex particles not only reduce the amount of water movement through the capillary blockage but also when cracking occurs, polymer latex film captures these channels and restricts their propagation. This results in increased flexural strength. The contact of the cellulosic fiber with the latex may have caused a certain hydrophobization of the same, protecting it from possible chemical attacks. 
However, there are minimum points at the intersection of the minimum concentration of latex $(0 \%)$ and the maximum concentration of cellulose $(10 \%)$ that can be attributed to the difficulty of molding the composite caused by the high content of cellulose, influencing its homogeneity and causing points of concentration of tensions [13].

However, with the reduction of the cellulose content, a decrease in the value of the rupture modulus was observed since the reinforcement was not enough. This same behavior was observed in the evaluation of the cellulose content and metakaolin content (Figure 1b). The maximum value for the modulus of rupture (around 12.6 MPa) was exactly in cellulose values around $5.7 \%$ and in the largest replacement of cement by metakaolin $(40.2 \%$, referring to the coded value of 1.41). Higher values of metakaolin probably resulted in a lower porosity of the matrix, resulting, possible, in higher values for the modulus of rupture [14]. In addition, due to the property of lowering the alkalinity in the matrix, possibly decreased cellulose degradation and improved the durability of the composites [15]. When the analysis was performed evaluating the \% latex and metakaolin variables, with the cellulose value at the central point (5\%) (Figure 1c), it was observed that there was a minimum area for the modulus of rupture response. This result can be explained by the lower reinforcement attributed to the lower quantity of cellulose, a smaller decrease in the number of pores, with the replacement of only $22 \%$ of metakaolin reducing its resistance and for the content $0.06 \%$ of latex, resulting in less modification of the cement matrix. Thus, it was observed that the best conditions analyzed to maximize the value of the rupture modulus were the combinations of the values of cellulose in $8.5 \%$, of latex in the value of $0.249 \%$ and of metakaolin in the central point (19\%).

For the absorption response, it was observed that equation 2 was significant, with a coefficient of variation $\left(\mathrm{R}^{2}\right)$ of 0.92 , for a confidence level of $90 \%$. In this way, it was possible to construct the response surfaces for the absorption (Figure 2).

$$
\begin{aligned}
& (\mathrm{A})=23.4+14.2\left(\mathrm{X}_{\mathrm{cel}}\right)+6.7\left(\mathrm{X}_{\mathrm{cel}}\right)^{2}-1.3\left(\mathrm{X}_{\mathrm{Lat}}\right)-2.9\left(\mathrm{X}_{\mathrm{Lat}}\right)^{2}+0.6\left(\mathrm{X}_{\mathrm{Mk}}\right)-3.2\left(\mathrm{X}_{\mathrm{Mk}}\right)^{2}-2.3\left(\mathrm{X}_{\mathrm{cel}}\right) \\
& \left(\mathrm{X}_{\mathrm{Lat}}\right)-0.6\left(\mathrm{X}_{\mathrm{cel}}\right)\left(\mathrm{X}_{\mathrm{Mk}}\right)-0.7\left(\mathrm{X}_{\mathrm{Lat}}\right)\left(\mathrm{X}_{\mathrm{Mk}}\right)
\end{aligned}
$$

According to Figures 2a,b, it was possible to observe the influence of the variables $\mathrm{X}_{1}$ (cellulose), $\mathrm{X}_{2}$ (latex) and $\mathrm{X}_{3}$ (metakaolin) in the absorption value of the composite. It can be observed that, when analyzing only variable $\mathrm{X}_{1}$, large amounts of cellulose in the composite results in higher values for absorption, with a maximum value of approximately 60\%, independent of the concentrations used for latex and metakaolin. This fact, possibly, was due to the hydrophilic nature of cellulose, which absorbs water when in contact with moisture. 
(a)

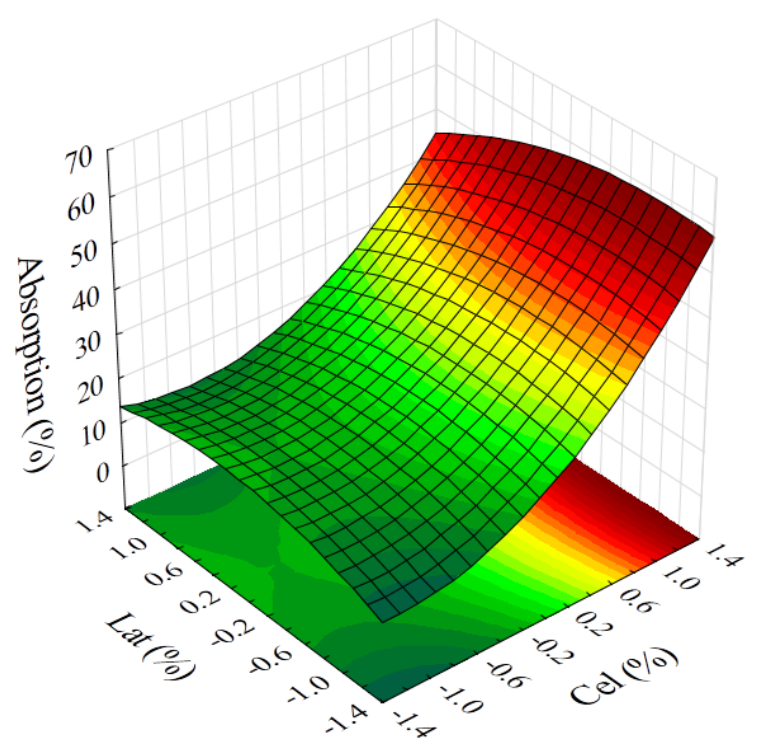

(b)

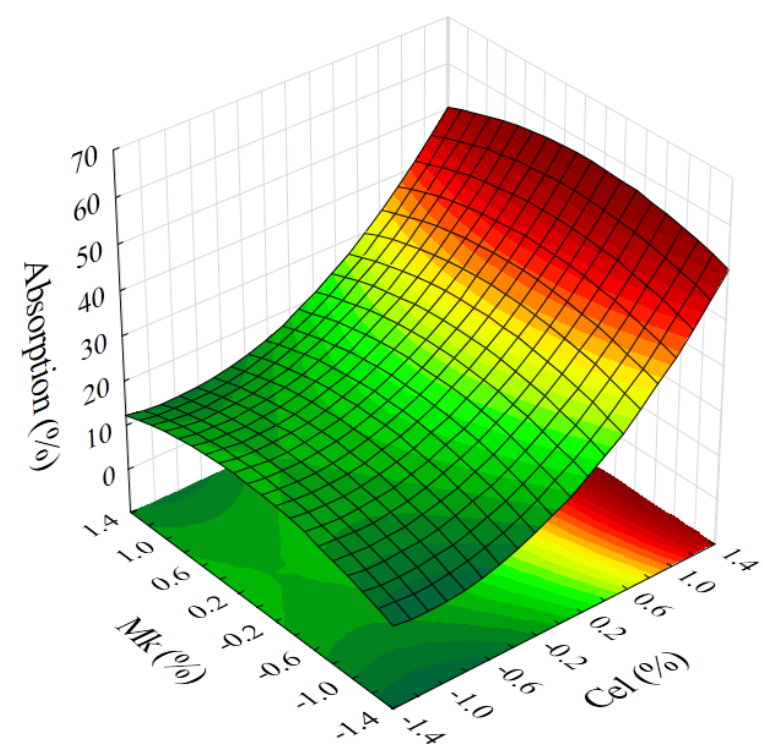

(c)

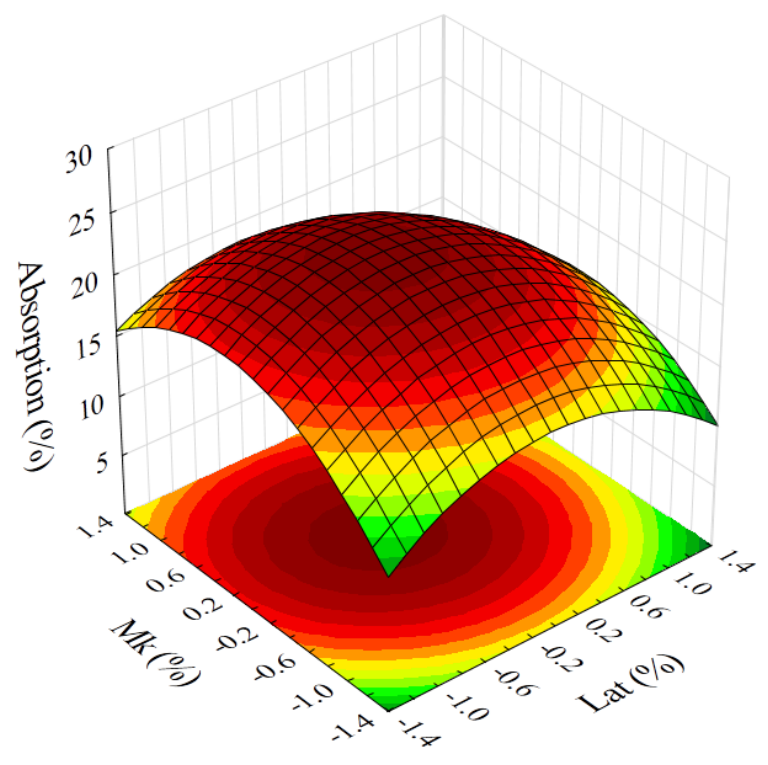

Figure 2: Surface response to the absorption - (a) \% metakaolin in the central level $\left(\mathrm{X}_{3}=0\right)$; (b) \% latex in the central level $\left(\mathrm{X}_{2}=0\right)$; (c) \% cellulose in the central level $\left(\mathrm{X}_{1}=0\right)$

According to [16] the absorption of water is one of the main problems that limit the application of materials based on cellulose, as this affects dimensional stability, mechanical properties and durability. However, there are minimum regions for the absorption value when working with combinations of variables. In the percentage of cellulose around point -1 $(1.5 \%), \%$ latex value at the maximum point of $1.41(0.249 \%)$ and metakaolin at the central point equal to 0 (19\%), a minimum absorption value was observed, around $11.54 \%$. 
When analyzing for the same value of cellulose, metakaolin at the maximum point of 1.41 (40.2\%) and latex at the central point equal to 0 (0.115\%) (Figure 2b), the absorption value was $11.23 \%$. When the values found for the first combination and the second combination were compared, it was observed that the values for absorption were statistically the same. Thus, it was possible to affirm that only the cellulose variable (X1) is significant for the analysis of the absorption response. Possibly a better dispersion of the latex or a longer time of contact with the cellulose could result in a different behavior after the 28 days of cure, ensuring, possibly, not only the modification of the cementitious matrix, also increasing its resistance to chemical attacks and greater resistance, as decrease the hydrophilicity of the cellulose, resulting in lower values for absorption. After analyzing the response surfaces for the rupture modulus and the absorption, it was possible to understand the behavior of the composites against the variables chosen for the study (cellulose, latex and metakaolin), within the ranges used, showing the importance of this analysis for the possible utilization of natural fibers added of latex and replacement of part of cement by metakaolin in cement matrix.

\section{CONCLUSIONS}

- The use of natural fiber (cellulose) increased the strength of the composite.

- The highest percentage of latex used in the planning $(0.249 \%)$ possibly caused a certain hydrophobization of cellulose fiber, resulting in greater resistance to rupture.

- Use of metakaolin as a substitute for cement possibly resulted in the lower porosity of the matrix, resulting in the increase of the modulus of rupture.

- The best condition analyzed to maximize the value of the rupture modulus was the combination of the values of cellulose in $8.5 \%$, of latex in the value of $0.249 \%$ and of metakaolin in the central point (19\%).

- Cellulose is the most significant variable in the analysis of the absorption of the composite due to its hydrophilicity.

- Thus, it was possible to observe that the modification of cellulose fiber with the use of latex, together with the replacement of part of cement by metakaolin, is a route that can be used in the civil construction since correctly studied the combination between these variables.

\section{ACKNOWLEDGEMENTS}

The authors would like to acknowledge CNPq, CAPES and FAPEMIG for supporting this work.

\section{REFERENCES}

[1] Silva, R., Haraguchi, S.K., Muniz, E.C., Rubira, A.F., 'Aplicações de fibras lignocelulósicas na química de polímeros e em compósitos’, Quim. Nova. 32 (3) (2009) 661-671.

[2] Onuaguluchi, O. and Banthia, N., 'Plant-based natural fibre reinforced cement composites: A review’, Cem. Concr. Compos. 68 (1) (2016) 96-108.

[3] Lima, P.R.L., Toledo-Filho, R., 'Uso de metacaulinita para incremento da durabilidade de compósitos à base de cimento reforçados com fibras de sisal’, Ambiente construído. 8 (4) (2008) 7-19.

[4] Macvicar, R., Matuana, L. M., Balatinecz, J.J., 'Aging mechanisms in cellulose fiber reinforced cement composites’. Cem. Concr. Compos. 21 (3) (1999) 189-196.

[5] Mohanta, N., Acharya, S.K., 'Fiber surface treatment: Its effect on structural, thermal, and mechanical properties of Luffa cylindrical fiber and its composite', J. Compos. Mater. 50 (22) (2015) 1-15.

[6] D’Almeida, A.L.F.S., Calado, V., Barreto, D.W., 'Acetilação da Fibra de Bucha (Luffacylindrica)', Polímeros: Ciência e Tecnologia. 15 (1) (2005) 59-62. 
[7] Motta, L.A.C., John, V.M., Agopyan, V., 'Thermo-mechanical treatment to improve properties of sisal fibres for composites', Mater. Sci. Forum. 636-637 (2010) 253-259.

[8] Claramunt, J., Ardanuy, M., García-Hortal, J.A., 'Effect of drying and rewetting cycles on the structure and physicochemical characteristics of softwood fibres for reinforcement of cementitious composites'. Carbohydr. Polym. 79 (1) (2010) 200-205.

[9] Rabello, M. 'Estudo da influência do Metacaulim HP como adição de alta eficiência em concretos de cimento Portland', Metacaulim do Brasil. (2003) 1-65.

[10] Bentur, A. and Mindess S., 'Fibre reinforced cementitious composites', 2nd Edn (GrãBretanha, Taylor \& Francis, 2007).

[11] Rilem. Technical Committee 49 TRF. 'Test for determination of modulus of rupture and limit of proporcionality of thin fibre reinforced cement section', Matériaux et Constructions. 17 (102) (1989) 441-443.

[12] Savastano Jr., H., 'Materiais à base de cimento reforçados com fibra vegetal: reciclagem de resíduos para a construção de baixo custo', Tese (Livre-Docência) - Escola Politécnica da Universidade de São Paulo, São Paulo.(2000).

[13] Pimentel, M.G., Borges, J.P.C., Picanço, M.S., Ghavami, K., 'Resposta à flexão e análise de tenacidade de argamassas reforçadas com fibra de Curauá', Revista Matéria. 21 (1) (2016) 18-26.

[14] Antoni, M., Rossen, J., Martirena, F., Scrivener, K., 'Cement substitution by a combination of metakaolin and limestone’, Cem. Concr. Res.42 (12) (2012) 1579-1589.

[15] Wei, J., Ma, S., Thomas, D.G., 'Correlation between hydration of cement and durability of natural fiber-reinforced cement composites', Corros. Sci.106 (1) (2016) 1-15.

[16] Moon, R.J., Martini, A., Nairn, J., Simonsen, J., Youngblood, J., 'Cellulose nanomaterials review: structure, properties and nanocomposites', Chem. Soc. Rev.1 (7) (2011) 3941-3994. 